\title{
THE SUNNII-SHT̄AH CONFLICT AND THE SEARCH FOR PEACE IN INDONESIA
}

\author{
Said Agil Siradi \\ The National Board of Nahdlatul Ulama, Jakarta - Indonesia
}

\begin{abstract}
This article attempts to scrutinize the phenomenon of theological contestation in Indonesia, as represented by the Sunnite and Shi'ite conflict in the region of Sampang, East Java. The conflict has occurred due to Muslims' inability to withstand the differences among them, so that violence is considered a way of final settlement. In this paper, the author will try, therefore, to analyze theological problems between the Sunnite and the Shi'ite in the region. It has been widely known that the Sunnite and the Shi'ite came out of the basis of similar truth, and, in fact, they share the same spirit of glorifying Islam around the world. In this way, all Muslim communities in the world, including the Sunnite and the Shi'ite, should be able to put their theological differences as God's graces and the blessing of life, not as the point of conflict and disharmony.
\end{abstract}

Keywords: Sunnite, Shi'ite, theological contestation.

\section{Introduction}

Theological problems will always attract attention of religious adherents regardless of their religion and faith. This is because such problems closely relate to their belief in the Hereafter life. People who believe in "another" eternal life after the worldly life will put their great attention to the theological discourses.

Today, Muslims are often faced with a variety of theological statements which claim that a certain group is considered disbelievers while another is the only right and pious. The facts have even shown that there has been a lot of violence in the name of theology or religion that burst in several regions of Indonesia. Such acts can be seen as a form of "mistaken love" as a result of "blind faith" held by certain 
religious adherents. People who did such misconduct have been actually trapped onto textual meaning of the religious texts, which in turn results in many biases that lead to violent and other destructive actions.

Some people tend to be more oriented to the belief that the afterlife is more promising than the worldly life. The reason is that in the Hereafter humans are promised a lot of luxury and happiness. It is in this context that some religious believers do violent actions for the sake of "a special reward" from God for their "jihād" during their life. However, the problem lays, whether or not the religion revealed by God through His messengers encourages people to commit crimes and conduct violent actions, while the teaching of all religions in the world puts great emphasis on non-violent actions? It is certainly Man who distorts either individually or collectively religious teachings for their own interests. ${ }^{1}$ This is because when violent actions are re-tracked based on a few incidents of violence in the name of faith, many other factors that influence such violent actions are found. In other words, it is not merely religious teaching which causes the violence. This is, however, not to deny that the issue of religious fanaticism often leads to the violent conflicts. These wrong deeds, nonetheless, do not come out of religious doctrines, but rather result from people's misinterpretation in understanding religious texts in the holy books.

Islam, as the religion of the majority of Indonesian people, extremely rejects all forms of violence. It has been revealed as a religion of mercy and peace to the world as stated in the Qur'an (alAnbiyà' verse 107): “And We sent thee (Muhammad) not but as a mercy for all creatures."’ The Prophet Muhammad also stated: "Surely I was sent to perfect good character" (a Hadith narrated by alBukhāri). These two religious texts prove that Islam strongly encourages its followers in order to spread love to others, and avoid all forms of violence.

1 Wim Beuken and Karl-Josef Kuschel (et.al), Agama sebagai Sumber Kekerasan? (Yogyakarta: Pustaka Pelajar, 2003), p. ix.

2 Nur Syam asserts that Islām has been revealed as a grace for all human and other creatures of Allāh (raḥmah li al-álamin), not only for Muslims (rahmah li al-Muslimīn). Therefore, respect and love are among the main teaching in Islam. See Nur Syam, Tantangan Multikulturalisme Indonesia (Yogyakarta: Kanisius, 2009), p. 60. 
Recent phenomena of violent acts committed by a certain group of Indonesian Muslims, including the case of Sunni-Shi'ah conflict in Sampang, East Java, present a contradictory picture. Muslims seem to fail to deal with the differences among them, so that violence is considered as a sole way of settlement. Therefore, in this paper the author will try to analyze the theological problems faced by the Sunni group and the Shi'ah community in Sampang. The author tends to argue that based on historical facts these two groups can actually look for common ground in an attempt to reconciliation, for they share the same root, tawhid.

\section{Sunni and Shi'ah in Conflict}

The term of Sunni usually refers to Abl al-Sunnah group. ${ }^{3}$ This group verily loves sunnah (traditions) taught by the Prophet Muhammad. The spirit of Sunni teachings has actually existed since the Prophet's life-time, but it was firmly established as a school of Islamic theology after the life-times of Abū Ḥasan al-Ash'arī and Abū Manșūr al-Mātūridi. Abū Hasan al-Ash'arī was initially one of the Mu'tazilah disciples, but due to his dissatisfaction to its doctrines of theology he left the Mu'tazilah. ${ }^{4}$ Once out, he subsequently founded a new school of theology that is identified according to his name, namely Ash'ariah.

In addition to al-Ash'arī there was also al-Imām Abū Manșūr alMāturidi. Al-Măturidi was one of the leaders of Sunni theology who base his theological views on the sunna of the Prophet. ${ }^{5}$ The very basic principle of the teachings of Sunni theology lays on the basis of teachings which have been performed by the Prophet Muhammad. Theological views held by this group of Islamic theology are, therefore, very moderate and they also put great respect to ethical views in dealing with differences.

Shi'ah arose from political factions, especially in the post-

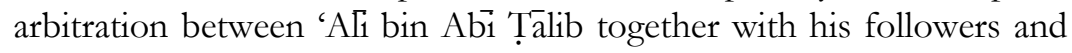
Mu'awiyah bin Abi Sufyān along with his proponents. Those who were very fanatical about 'Ali were subsequently called the Shi' at 'Ali (Group

\footnotetext{
3 Muștafa al-Shak'ah, Islam bilā Madhābib, 14th edition (Cairo: al-Dār al-Mișriya alLubnāniya, 2000), p. 409.

${ }^{4}$ Harun Nasution, Teologi Islam: Aliran-Aliran Sejarah Analisa Perbandingan (Jakarta: UI Press, 1986), p. 67.

5 Ibid., p. 76.
} 
of 'Ali), whereas those who were very fanatical about Mu'a wiyah were then commonly called as the $S h \bar{i}$ 'at $M u^{\prime} \bar{a}$ wiyah (Group of Mu'awiyah). But over time, the use of the term is more synonymous with the followers of 'A $\overline{l i}$ ibn Abi Tăalib. ${ }^{6}$ This theological stream confirms that imamah is an important part of religious teachings. ${ }^{7}$ They truly love the abl al-bayt (the descendants of 'Ali). They believe that the abl al-bayt is more important in holding the reins of power after the Prophet, which is in this case 'Ali is the most proper Muslim leader. ${ }^{8}$ It was such love which has made the Shi 'ite group so apathetic with other Islamic groups.

There are two schools of theology in the Shi'ah Twelve (Shi'ah Ithnay 'Asharìya), namely Ușüliyah and Akhbäriyah. The term usütiyah is derived from usūl (the plural form of the word asl, which means basic, fundamental, principle or source. In the tradition of Shi'ah's figh thought, the Ușuliyyah group is very rationalist by placing reason as a principle or source of Islamic law, so that on this basis they are known as Ușuli. Among the Ușūi scholars were people who were strongly influenced by the figh thought of al-Imām al-Shäfi $\overline{1}$, one of great Sunni's scholars in the field of Islamic jurisprudent (figh). ${ }^{\text {' While the }}$ term Akhbāijyah is derived from the word akhbar (the plural form of the word khabar), which means news or information. In the science of Mustalah al-Hadith, the term khabar is used for another term of Hadith of the Prophet. In the context of Shi'ah's tradition, the term khabar does not merely refer to Hadith of the Prophet, but it also refers to the Hadith of Shi'ah's imams. Therefore, to a certain extent, the Akhbāri

\footnotetext{
${ }^{6} \mathrm{Al}-S h a k ' a h$, Islam bilā Madhähib, p. 171.

7 Al-Shaykh Muhammad Ḥusain al-Faqih, Limādhā Anā Shi'⿳亠丷厂?, 3 3rd edition (Beirut: AlGhadir li al-Dirāsāt wa al-Nashr, 1996), pp. 31-6.

${ }^{8}$ Fadil Su'ud Ja'fari, Islam Syiah (Malang: UIN-Maliki Press, 2010), p. 25.

9 They see ijtibäd as an important matter, since it is considered a mere way to discover laws from their original sources. However, the scholars of Shi'ah do not recognize analogy (qiyas) as a source of law, as the majority of Sunni scholars are unanimous to recognizes qiyas as a means of ijtihäd. To Shi'ah there are four sources of Islamic laws, namely the Qur'an, the Sunnah, ijmä, and reason instead of qiyas. In addition, Shi'ah argues that reason serves as a means to excavate and understand shari' $a h$ as far as it does not violate the Qur'an and the Sunnah. See Abdul Rouf, "Melacak Akar Pemikiran Fikih Ja'fari” in Al-Huda, No. 13, Volume V (2007), pp. 30-1.
} 
people are parallel to $A b l$ al-Hadith in the perspective of Sunni fiqh, which is very conservative. ${ }^{10}$

In the history of the Islamic caliphate, there were rulers who stated their "theo-political" views which considered the Shicite as having gone astray. This is because the Shi'ite preferred opposition against the government. ${ }^{11}$ Being the opponents against the ruling group was, at that time, closely related to the past history experienced by the Shi'ah community. Experiencing a great lose in the past caused them suffer from a psychological burden and, therefore, they were eager to take a revenge. A historical account has even shown that on one occasion, during the Seljuk Dynasty, it was Taghrul Bek, the first king who issued the policy to burn all libraries of Shi'ah in Baghdad, Iraq. The libraries were both storehouses of valuable classical works and centers of works of many Shi'ah's scholars in various disciplines of science, including theology and humanities. ${ }^{12}$ However, due to the arrogance and blind fanaticism, these monumental works were burnt and destroyed.

In short, the Sunni-Shi'ah conflict was mainly rooted in political matters. The issue was then shifted, however, into theological sphere as an effort to strengthen each group's movement. When political issues are mixed with theological problems, the politics — as a means of grasping power-has increasingly found its legitimacy. As a result, the conflict tends to be fiery. When this occurs, the disputes among Muslims would be difficult to reconcile. Muslims need to be more open, therefore, to differences, for Islamic teachings they held are equally derived from two same main sources, namely the Qur'an and the Hadith. Moreover, the differences in interpretation should be seen as a given nature of human and a blessing of God.

\footnotetext{
10 The Akhbariya severely limits the role of the clergy. It sees that the principles of Islamic shari'ah must be totally based on the application of tradition, not solely on the fatwa of the scholars. What is meant by the tradition here is the necessity to return to the tradition of the previous Imāms of Shi'ah. The Akhbāriya employs, de jure, the principles of Ash'ari theology, in which they also acknowledge the existence of kashf (rational intuition) to solve certain problem. See Cyril Glasse, "Akhbäri," Ensiklopedia Islam Ringkas (Jakarta: PT Raja Grafindo Persada, n.d.), p. 17.

${ }^{11}$ Musthafa Rafi'i, Islam Kita: Titik Temu Sunni-Syi'ab (Jakarta: Milestone, 2013), p. 23.

12 Ibid., p. 23.
} 
The difference between Sunni and Shi'ah must be understood as a must-phenomenon of life. This implies that Muslims should accept and respect each other in order to maintain harmony among them. It has been obviously known that Shi'ah is different from Sunni in terms of the concept of imamah (leadership). Unlike Sunni, which views imamah only as a sunnah matter, Shi'ah regards imamah as one of fundamental teachings of Islam. To Shi'ah, in order to be "a true follower" of Shi'ah a person must believe in imämah. In other words, belief in imamab is a fard 'ayn (an obligatory matter). Moreover, imämah is a functional position of an imam (a priest) who serves as a religiopolitical leader for the whole Muslim community and for the sake of carrying out God's commands (al-amr bi al-ma'rüf wa al-naby 'an almunkar, inviting to the goodness, and forbidding the evil). ${ }^{13}$

The aforementioned doctrine has caused many internal conflicts between the Sunni and Shi'ah communities. The dispute has been sharpened due to a doctrine held by a group of the Shi' ah people who idolize 'Ali and consider him as a sacred figure. The group even regards three other companions, Abū Bakr, 'Umar, and Uthmān, as infidels. These people argue that the three companions wrested power, which in fact belongs to 'A $\overline{l i}$. The Sunni group, on the contrary, has different view from that of Shi'ah. According to the Sunni people, the three companions were also among the closest companions of the Prophet whose integrity of their Islamic faith is unquestionable. Therefore, the Sunni group is very cynical against the Shi'ah people who hold such a view and regard them as too outrageous in their claim. However, not all the Shi'ah followers hold such a view. There are groups of Shi' ah followers which hold a "moderate" view about the three companions. It is the Shi'ah Zaydiya who recognizes Abu Bakr, 'Umar, and 'Uthmān as the caliphs after the Prophet Muhammad. Unlike the previous group, the Zaydi members believe that the appointment of the three companions as the leaders of the Muslims were in order to maintain maslahah (the common good). The Zaydi argue that there were victims of war, waged by 'A $\overline{l i}$, who really

13 Bernard Lewis, Bahasa Politik. Islam, transl. by Ihsan Ali Fauzi Jakarta: Gramedia, 1994), pp. 44-5. 
intended to take revenge against him. ${ }^{14}$ For the sake of maslahab the three companions were, therefore, appointed and chosen as the caliphs in advance to preserve the unity of ummah. It is necessary to note, however, that to the Zaydi people, 'Ali remains a more important figure than the three other companions.

\section{The Sunni-Shi'ah Conflict in Indonesia}

Being the two largest schools of theology in Islam has often caused Sunni and Shi'ah get involved in dispute. Truth claims of each group often led to conflict and violence. The conflict between Sunni and Shi'ah has not occurred only in the Middle East countries, but it has also widely spread around the world, including Indonesia as a home to the world largest Muslim communities. The deadly conflict between these two groups in the Sampang Region in East Java on August 26, $2012^{15}$ was an obvious evidence on how vulnerable actually the two different communities, who live in Indonesia, are to conflict. Escalation of the conflict has even increased. The case of Sunni-Shi'ah conflict in Sampang was, actually, a matter of internal violence among Indonesian Muslim communities.

The Lingkaran Survei Indonesia (LSI) conducted a research on "religious discomfort in Indonesia" from 1 to 18 October 2012. The research has involved 1,200 respondents, and found that 41.8 percent of Indonesian "mainstream" Muslims feel uncomfortable to coexistence with Shi'ah people, while 46.6 percent of the respondents feel uncomfortable to live side by side with the Ahmadiya group. In addition to these findings, 15.1 percent of the respondents feel uncomfortable to live side by side with neighbors of different religions. ${ }^{16}$

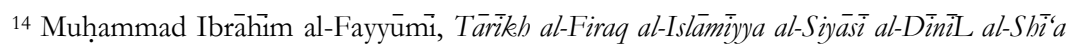
al-'Arabiyya wa al-Zaydìya (Cairo: Dār al-Fikr al-'Arabi, 2002), p. 308. See also AlShak'ah, Isläm bilā Madhbāhib, pp. 223-24.

15 "Menteri Agama Kutuk Kekerasan Agama Sampang," Republika. Available at http://www.republika.co.id/berita/nasional/umum/12/08/27/m9e6y5-menteriagama-kutuk-tindak-kekerasan-Shi'a-sampang. Accessed on Monday, August 27, 2012.

16 "Kekerasan atas Nama Agama Meningkat," Waspada Online, Available at http:/ / www.waspada.co.id/index.php?option $=$ com_content\&view $=$ article\&id $=26475$ 4:kekerasan-atas-nama-agama-meningkat\&catid=77:fokusutama\&Itemid=131. Accessed on Sunday, October 21, 2012.
} 
The aforementioned results of the LSI's survey show that Indonesian Muslims' resentment against Shi'ah group is still very high. 41.8 percent of Indonesian Muslims feel uncomfortable coexistence with Shi'ah people. To firmly state, the haters are dominated by Sunni people, indeed. This is because the vast majority of Indonesian Muslims adhere Sunni as their "official" theological school.

Muhammad Husain Fadlullah argues that a Muslim's affiliation to his school is nowadays greater than to Islam as religion. A Muslim who adheres to Sunni as his theological school would be likely very apathetic against other groups, as he was continuously "intoxicated" with the doctrines of Sunni since his childhood. They live in the shadow of creed and imagination, which are contained by the exclusivity of history and blind fanaticism of viewing other groups. ${ }^{17}$ The same is true with Shi'ah group as they live in doctrines, which impede their free movement, so that when they face and are confronted against different people they often regard them as hypocrite people and unbelievers whose blood is halàl. It is a regrettable matter, indeed, for Islam promotes and emphasizes the message of peace as its main doctrine.

One's affiliation to a certain sect or school has been increasingly driven by the accumulation of hard psychological problems, uncontrolled emotions, and the peculiarities of everyday life. ${ }^{18}$ This encourages them to make the school they adhere to a "new religion", which opposes other people of different schools. They tend to claim as if "the truth" is revealed only for themselves, and they, therefore, neglect other groups' truth and rights.

As a result of this fanaticism, Sunni followers and Shi'ah members are continuously involved within psychological and physical dispute and hostility. Each group's memories are crowded with various doctrines and traditions that have long been attached. T Diversity, in addition, is a common matter, which is also considered sunnat Allāh. Plurality is, therefore, an absolute and undeniable matter. It is a reality, which has been deliberately created by God. Maḥmūd Hamdi Zaqzūq asserts that Islam greatly appreciates all kinds of human community as a reality, which should not be an obstacle to the realization of unity, togetherness, and the ethos of mutual help among the human race.

${ }^{17}$ Muhammad Husain Fadlullah, "Kata Pengantar," Musthafa Rafi'i, Islam Kita, p. xvi.

${ }^{18}$ Rafi'i, Islam Kita, p. xvi. 
Plurality of thought should be addressed as a potential that can pave the way for unity. ${ }^{19}$

Nurcholish Madjid states that diversity or plurality of the human race is the will of God. The scriptures have also informed that human are created into different nation-states and tribes in order to them to know and respect each other. The plurality is subsequently evolved into forms of pluralism, a system of value in which diversity and pluralities are seen as a positive factor for the creation of common shared-values..$^{20}$

The act of blind fanaticism, which has been shown by Sunni and Shi'ah followers, should be viewed, therefore, as a form of selfishness due to their incomprehensive understanding of Islamic teachings as well as the limitedness of knowledge they posses. The ignorance has further caused the emergence of various issues, which led to suspicion, hatred, conflict, and violence among Muslims.. Sunni and Shi'i Muslims should, above all, realize that they are brothers who used to live in peace and mutual respect. The history of harmony they had shared in the past should be prioritized instead of the memory of hatred and suspicion.

\section{The Intersection between Sunni and Shi' $a$ ah}

The fact that Sunni and Shi'ah are different does not mean that they do not posses common values to share with. They can still find a common ground to play, not in the sense of "school unification", ${ }^{21}$ but rather in the same realm of sources, the Qur'an and Hadith. Muslims should, therefore, keep their minds open and their souls conscious by realizing that every person has difference in terms of his/her ability of thinking and of socio-cultural conditions. By doing so, Muslims can cultivate the sense of brotherhood and perpetuate mutual dialogues and coexistence among them. This is an important mission to accomplish in the midst of growing fanaticism, which threatens integration of the nation.

\footnotetext{
19 Mahmud Hamdi Zaqzuq, Reposisi Islam di Era Globalisasi, translated by Abdullah Hakam Syah (Yogyakarta: Pustaka Pesantren, 2004), p. 122.

20 Nurcholish Madjid, "Kata Pengantar," Islam Doktrin dan Pradaban (Jakarta: Paramadina, 1992), p. xxv.

${ }^{21}$ Rafi'i, Islam Kita, p. 61.
} 
The four schools of Sunni, Mālikìyah, Ḥanafīyah, Shäfīìah, and Hanābilah along with the two major schools of Shi'ah (the Shi'ah Ithna 'Ashariyah and the Zaydiyah) have, in fact, common agreement on the very basic terms and principles of religion (usiū). The term usū refers to the five pillars of Islam (Arkān al-Islam) and the six pillars of faith (Arkān al-Iman), emphasizing that there is no religion after Islam; no prophets after the Prophet Muhammad; entire messages in the Qur'an are true, the whole words of the Prophet in his Hadith are true; death and life after it are true, the Day of Resurrection and Judgment, rewards, punishments, heaven and hell are also true..$^{22}$ In these main dimensions both the Sunni and the Shi'i Muslims share common views although they may differ from each other in terms of interpretations. The differences of interpretation are a necessary matter amid the diversity of society. The differences also mark a dynamic of thought of a certain community.

Fanaticism is not a help in realizing peace among Muslim fellows and even between Muslims and non-Muslim fellows. The differences among schools in the fur $\bar{u}^{\prime} i$ (non-basic) matters should be understood, therefore, as a matter of responses and the dynamics of thought of scholars of each school. This is why the differences among Muslims should not be an excuse for blaming each other and viewing other Muslims as infidels.

None of the six schools neither denies certain religious principles nor adds things to them. The followers of these schools are, in fact, working together to build unity and to cooperate in order to achieve happiness and leave the various threats that surround them. ${ }^{23}$ The differences between Sunni and Shi'ah are limited merely on a matter of different perspectives in viewing the validity of argument (dalii) they employ. This is in line with the differences among the followers of the fiqh schools of Sunni. The Sunni and the Shi'i Muslims are, actually, very closely linked. The fact that the followers of al-Shafi'inah are just like the followers of the Shi'ah Imämiyah ${ }^{24}$ is just an example.

\footnotetext{
22 Ibid., pp. 61-2.

23 Ibid., p. 62.

${ }^{24}$ The Official Board of Shaykh of al-Azhar in Cairo has issued a fatw $\bar{a}$, which has been signed by the Grand Shaykh of Al-Azhar, Shaykh Mahmūd Shaltūt. The fatwa states: 1. Islam does not oblige Muslims to follow any particular sect or school. Every Muslim has the right to attend any school that is authoritative and fatwas that have been
} 
'Ali ibn Abi Țălib himself provided a good example of how to appreciate the differences in Islam. Musthafa Rafi'i has even said that 'Ali was the first person who established the foundation of unity. When Abu Bakr was opted as the Caliph the squabbles between the proponents of $\mathrm{Abu}$ Bakr and those of "Ali had almost occurred. However, due to 'Ali's strong commitment to maintain the unity of Muslim ummah, he gave great and full support to Abu Bakr, while saying: "We do not doubt about the goodness and righteousness of God that have been bestowed upon you. In this case, we see no problem that only you can handle it, not others. We do not deny your honor." 25

The same was true with the imams of the Sunni schools as they provided a good example in dealing with differences. Their actions obviously reflect the magnanimity light as great scholars. For example, when the Caliph al-Makmūn was about to make the book Al-Munvatta' as the official school of the country, al-Imām Mālik refused it. Mālik said: "O Amir al-Mu'minin, let people choose the views that are relevant to them". Al-Imām Abū Hanifah, as another good instance, once said: "It has also been my opinion, and this is certainly the best view I could produce. Whoever is able to present a better view, his view should be prioritized as a paramount truth, then."

Al-Imām al-Shāfíi once told: "O Ibrahim, follow no every view I have stated. You ought to have your own views; and that is religion." On one occasion al-Imām Ahmad ibn Hanbal also said: "Follow neither me, nor Mālik, nor Awza $\bar{i}$, nor Abü Hanifah, and nor others. Define the law based on the sources they use, namely the Qur'an and the Sunnah." The good examples have also been shown by the scholars of the Shi'ah Imämiyah and the Zaydi as they never picked up and followed entire religious laws of their imams except those of what they have understood according to the Qur'an and the Sunna.

codified in form of books. Those who follow certain school and moves to another school, it is not a problem for him to do so. 2. Ja'fari school as known as Shi'ah Imamiyah (the Shi'ah Twelve) is a school that is allowed to be used as a source of law like other schools of Sunni.

${ }^{25}$ Rafi'i, Islam Kita, p. 63-4. 


\section{Plurality as an Inevitable Matter}

Differences in many aspects of life are part of life itself. This is because human are born within different time and space in as much as various social, political, and cultural conditions. The fact that people in the world adhere to more than one religion or one religious sect is just a logical consequence.

Religious matters often lead to plurality. Thus, it would be unrealistic if one imagines that there would be only one religion. ${ }^{26}$ Diversity and plurality are undeniable realities, which have existed since long time ago. Moreover, the so-called a "village of globe" is an interesting concept where a person or a nation cannot live separately from the other. ${ }^{27}$.

Muslims should respond wisely to such a reality. Allāh has asserted in the Qur'-an (Al-Maida verse 48): "And if Allāh had enforced His will, He would have made you all one people, but He wishes to try you by that which He has given you. Vie, then, with one another in good deeds. To Allāh shall you all return; then will He inform you of that wherein you differed." It can be clearly observed through this verse that plurality is a necessity, which has been intentionally created by God in order to examine the level of human's faith. High tolerance and respect are needed in this case. This is because when Muslims reject the existence of plurality of thought, this means they reject the will of God, deliberately creating differences among humans.

Allāh in the Qur'ān (al-Hujarāt verse 13) also says: "O mankind verily We created you from a male and a female and We have made you into tribes and nations that you may recognize one another. Verily, the noblest among you, in the sight of God, is he who is the most righteous among you. Surely, Allāh is All-Knowing, All-Aware." 28 The verse gives an overview of how people should manage the differences

\footnotetext{
${ }^{26}$ Syahrin Harahap, Teologi Kerukunan (Jakarta: Prenada, 2011), p. 3.

27 Jamal A. Badawi, Hubungan Antaragama: Sebuah Perspektif Islam dalam Equality and Plurality dalam Konteks Hubungan Antaragama (Yogyakarta: CRSD, 2008), p. 43.

28 Mustafa Ceric, a Great Mufti of Bosnia-Herzegovina, condemns Muslim groups who do not respect plurality. This is beacuse, according to him, there many Qur'anic verses, which state this matter. This statement is cited by John L. Esposito in Masa Depan Islam: Antara Tantangan Kemajemukan dan Benturan dengan Barat (Bandung: Mizan, 2010), p. 170. See also Mustafa Ceric, "State of The Statebof Bosnia-Herzegovina," a lecture presented in Muslim Community Association in San Jose, CA in November 3, 1997. Available at http://www.sunnah.org/event/ceric/dr.htm.
} 
wisely. The differences among Muslims should be, therefore, seen as a necessity in order for them not to be trapped in blind fanaticism, which potentially harms themselves. Once they could respond wisely to the diversities, Muslims could bring about a peaceful manner and respect among them.

Islam highly respects plurality of thought ${ }^{29}$ as an inevitable matter for human. The following verse (Hüd verse 118-119) is important to be contemplated, as Allāh says: "And if thy Lord had willed, He would have surely made mankind one people; but they would not cease to differ. Except those on whom thy Lord has had mercy, and for this has He created them." Through this verse, according to Mahmūd Hamdi Zaqzūq, Islam actually appreciates all kinds of communities as a reality, which should not turn to be an obstacle to the creation of unity, togetherness, and the ethos of mutual help between people. Plurality should be addressed as a potential that can pave the way for unity. 30

Pluralism has become a widely-discussed issue in public debates nowadays. ${ }^{31}$ In the $21^{\text {st }}$ century humans are hardly faced with continuous diversities, which might lead to clashes. To avoid unnecessary clashes the idea of pluralism is then presented as a concept that invites people to be able to appreciate any differences. It seems that the idea of pluralism invites people to enjoy the feast of peace with their fellows. ${ }^{32}$

${ }^{29}$ The Oxford English Dictionary defines pluralism as a character to be plural, and in the political world it is defined as: (1) A theory against the monolithic power of the state and even advocated for increased devolution and autonomy of the main organizations that represent a person's involvement in the community; also that the power should be divided among the existed political parties. (2) The presence of tolerant diversity of ethnic groups and cultures within a society or country, the diversity of beliefs, or attitudes that exist in an agency or institution, and so on. See J. A. Simpson and E. S. C. Weiner, The Oxford English Dictinory, Vol. XI, the $2^{\text {nd }}$ edition (Oxford: Clarendon Press, 1989), p. lxxv.

30 Zaqzuq, Reposisi Islam di Era Globalisasi, p. 122.

31 The paradigm of Western society about religion has been much changed from their predecessors. The idea thinking has influenced the Eastern societies that also assess the importance of pluralism. It is now, then, the time to produce a progressive interpretation of the text for the sake of Islamic world and its civilization. See Harold Coward, Pluralisme Tantangan bagi Agama-agama (Yogyakarta: Kanisius, 1989), p. 77.

32 Abdul Aziz Sachedina, Kesetaraan Kaum Beriman: Akar Pluralisme Demokratis dalam Islam, transl. Satrio Wahono (Jakarta: Serambi, 2002), p. 48. 
The desire for peace is a basic instinct of human. Human, as the best creature of God, are always keen on peace and harmony with their human fellows. It has also been emphasized in the Qur'an (al-Baqarah verse 213), as Allāh says:

\begin{abstract}
Mankind were one community, then they differed among themselves, so Allah sent Prophets as bearers of glad tidings and as warners, and sent down with them the Books containing the truth that $\mathrm{He}$ might judge between the people wherein they differed. But now they began to differ about the Book, and none differed about it except those to whom it was given, after clear signs had come to them, out of envy towards one another. Now has Allāh, by His command, guided the believers to the truth in regard to which they (the unbelievers) differed; and Allāh guides whomsoever $\mathrm{He}$ pleases to the right path.
\end{abstract}

The principle of unity of humankind is the main foundation and the very root of pluralism. ${ }^{33}$ Although people are different in terms of beliefs or religions they adhere to from one to another, they are still the same creature of God. Therefore, the attitude of respect and acceptance in addressing the diverse plurality should be continuously emphasized. It is pivotal to note that the Prophet Muhammad was the best instance in terms of his noble attitude towards plurality and diversity. He never compelled people to adhere to Islam. The main point of morality is, therefore, recognition and respect toward plurality and diversity as a necessary phenomenon of life created by God.

\title{
Differences in Theology and the Search of Peace
}

The word theology literally means the science of divinity. The word is derived from Theos, which means God, and logos, which means science. ${ }^{34}$ The science of God deals with the existence, nature, and power of God, God's relationship with human, and human's relationship with God, and the relationships among human that are based on the values of deity. ${ }^{35}$ The discussion about the context of Man's relationship with God is also part of theological realm..

33 Ibid., p. 51.

34 See A. W. Lane, Arabic-English Lexeion (Cambridge-England: The Islamic Society Trust, Format, 1984).

${ }^{35}$ Harahap, Teologi Kerukunan, p. 15. 
Islam highly emphasizes the values of peace. There is no link, in fact, between violence and religion. Violence is a mere socio-political phenomenon. ${ }^{36}$ On the contrary, religion exhorts people to maintain peace and harmony with others as a way of life to achieve happiness. Violence often arises from socio-political issues, which are then shifted into the theological realm. The past instances show how the conflicts between Sunni and Shi'ah have been caused, above all, by power struggle and political dispute.

The Sunni-Shi'ah conflict that occurred in Sampang, likewise, was not caused by a theological issue, in fact. Instead, it was a domestic issue between Tajul Muluk and Rois, his sibling. ${ }^{37}$ Both have followers. As a leader in their respective village, their followers have high empathy; an empathy, which has resulted in a blind fanaticism and led to violent conflict and murder. It is somehow ironic, for religions-as the creators of peace-are often misused by irresponsible parties to gain and sustain their personal or communal interests.

Islam itself means peace. It has taught noble values of peace. Moreover, it has been rapidly spread across the world due to its strong commitment to the enforcement of the principles of peace. Islamic warfare in the past should be viewed as a sole form of defense and survival. It should not, in addition, be regarded as an aggression and a way to attack other people due to their different beliefs. If Islam uses war as a way to spread its teachings, as some people argue, its rapid grow and existence would have never been inconceivable. There is no religion that can thrive through bloodshed and terror, indeed. ${ }^{38}$ That is why da'wah (religious calls) in Islam is conducted in a peaceful and polite manner.

The advent of Islam is evidently obvious. Many Quranic verses also emphasize that the Prophet Muhammad was sent to be a blessing

\footnotetext{
36 Asghar Ali Engineer, Liberalisasi Teologi Islam: Membangun Teologi Damai dalam Islam (Yogyakarta: Alinea, 2004), p. 183.

37 See Koran Jurnal Nasional (28 august 2012). The Minister of Religious Affairs, Suryadharma Ali, has confirmed that the violent conflict Nangkernang, Sampang, East Java was not a conflict between Sunni and Shi'ah. The outbreaks of sectarian violence in Sampang ascertained due to family conflict between two siblings, namely Muluk and Rois.

38 Empirical reality in the history of Islam has shown that Islam was not spread by sword. Instead, it was brought by Sufi leaders through peaceful means that emphasize love and peace. See Engineer, Liberasi, p. 191.
} 
to all human..$^{39}$ As a religion of grace, Islam strongly condemns violent behaviors. On the contrary, Islam teaches its adherents to promote a peaceful means of dialogue in resolving any issues. It is obviously incorrect when Islam, as a religion of mercy, is understood as teaching its followers destructive actions such as killing and violent acts. Any forms of religious violence are, therefore, a mere guise to legitimize the vested interests of certain irresponsible group and people. ${ }^{40}$

The Prophet Muhammad himself was not sent but to improve and perfect the morals of human. ${ }^{41}$ The improvement of human's character means a big dream to make the earth as a place where human share love, affection, peace and living together in harmony. Love and affection are among the noble concepts of Islam that emphasize mutual respect and spreading of peace.

The Qur'an has stressed the importance of mutual respect amid the differences among human. Allāh in the Qur'an (al-'Ankabūt verse 46) says: "And argue not with the People of the Book except with what is best; but argue not at all with such of them as are unjust. And say, "We believe in that which has been revealed to us and that which has been revealed to you; and our God and your God is one; and to Him we submit." The verse emphasizes the attitude of respect toward the People of the Book. Muslims, as such, should respect their Muslim fellows. In other words, when Muslims, Sunni or Shi'ah, fail to share common roots, they contradict to this verse.

Islamic commitment to peace is, above all, high. In another Qur'anic verse (Āli 'Imrān verse 110) Allāh says: "You are the best people, born for all mankind; you enjoin what is good and forbid evil and believe in Allāh." This verse suggests that Islam invites all mankind to do good and forbid evil deeds. Violence is one of the unjust actions that should be shunned by Muslims.

In addition, there are verses in the Qur'an as a comparison in viewing the Sunni-Shi'ah conflict. Allāh (Āli-'Imrān verse 67) says: "Abraham was neither a Jew nor he was a Christian, but he was ever inclined to God and obedient to Him, and he was not of those who associate gods with God." Husein Muhammad asserts that the verse

\footnotetext{
39 See sura Al-Anbiyā' verse 107 mentioned above.

${ }^{40}$ Engineer, Liberalisasi, p. 193.

${ }^{41}$ See the aforementioned hadith of this matter.
} 
implies that religious identity and the name of a religion are not among important matters. Recognition of the oneness of God and surrender solely to Him, as the very paramount matters of religious teaching, become the emphasized concern of the verse. ${ }^{42}$ In the context of the Sunni-Shi'ah conflict, the verse illustrates that the difference in schools of Islamic thought should not be regarded as an important matter. The most important things are Muslims' recognition of the oneness of Allāh and total submission to Him along with their actions to create mutual respect and helpfulness as well to spread peace. The attitudes that Muslims must reject are attitudes, outlooks, and practices, which equate God with His creatures.

Therefore, both the Sunni and Shi'i Muslims should be able to appreciate the differences in schools of Islamic thought and to wisely respond to them. The reason is that both Sunni and Shi'ah can still find a common ground in many ways. Thus, there is no reason for the followers of each school of Islamic thought to blame each other, to view each other as infidels, and even to kill each other. Islam strictly prohibits these actions and really condemns them. ${ }^{43}$ The followers of Sunni and Shi'ah should let themselves together with people of different religions live in peace. By creating harmony in life, they can help each other for the sake of common goods and the advancement of Muslim communities at large in the future.

\section{Conclusion}

Both the Sunni and Shi'i Muslims are basically brothers who were born in the spirit of truth to maintain peace and harmony not only among them but also among human and other creatures in general. The differences among them should be seen merely as a result of different social and political conditions, not that of theological reasoning. Muslims should, therefore, view the differences among them as the good graces and blessings of life bestowed by God. Mutual

\footnotetext{
${ }^{42}$ Husein Muhammad, Mengaji Pluralisme kepada Mahaguru Pencerahan (Bandung: Mizan, 2011), p. 8.

${ }^{43}$ Humans should, actually, respect to each other. One must not impose his will in belief. Moreover, one should not disdain those of different beliefs, since it is a life choice that should not be forced. It is a taboo to insult other people of different beliefs. See Burhanuddin Daya, Agama Dialogis: Merenda Dialektika Idealita dan Realita Agama Hubungan Antaragama (Yogyakarta: Mataram-Minang Lintas Budaya, 2004), p. 23.
} 
respect is necessary to promote positive attitude in dealing with differences.

Islam posits itself as a religion of mercy, compassion, and peace spreader for all human races. Emphasizing mutual respect, as a way for the creation of a prosperous life as well as peaceful and civilized society, is a necessity. Moreover, Islam is a religion that strongly condemns any kinds of violent actions. Truth claim has often become the initial phase of violent acts. As the truth belongs merely to Allah Himself, no one person or group can claim the truth as their own exclusively. Claiming truth means acting like God, and this is considered shirk in theological sense, that is the biggest sin in which God will not forgive it forever. Above all, Muslims should be able to act wisely in responding to and in dealing with religious plurality and other sort of differences. []

\section{References}

\section{Books and Articles}

Badawi, Jamal A. Hubungan Antar Agama: Sebuab Perspektif Islam dalam Equality and Plurality dalam Konteks Hubungan Antar-Agama. Yogyakarta: CRSD, 2008.

Beuken, Wim \& Karl-Josef Kuschel (et al). Agama Sebagai Sumber Kekerasan?. Yogyakarta: Pustaka Pelajar, 2003.

Ceric, Mustafa. "State of The Statebof Bosnia-Herzegovina", a lecture presented at Muslim Community Association in San Jose, CA, 3 November 1997, http:/ /www.sunnah.org/event/ceric/dr.htm

Daya, Burhanuddin. Agama Dialogis: Merenda Dialektika Idealita dan Realita Agama Hubungan Antaragama. Yogyakarta: MataramMinang Lintas Budaya, 2004.

Engineer, Asghar Ali. Liberalisasi Teologi Islam: Membangun Teologi Damai dalam Islam. Yogyakarta: Alinea, 2004.

Esposito, John L. Masa Depan Islam: Antara Tantangan Kemajemukan dan Benturan dengan Barat. Bandung: Mizan, 2010.

Faqiih (al), al-Shaykh Muhammad Husayn. Limāadhā Anā Shīîr? Beirut: al-Ghadir li al-Dirāsāt wa al-Nashr, the 3rd edition, 1996. 
Fayyūmi (al), Muhammad Ibrāhim. Târikh al-Firaq al-Islamìyah al-Siyas̄i al-Dinī: al-Shì'a al-'Arabīyah wa al-Zaydìyah. Cairo: Dār al-Fikr al'Arabi, 2002.

Glasse, Cyril. “Akhbāriy” in Ensiklopedia Islam Ringkas. Jakarta: PT Raja Grafindo Persada, n.d.

Harahap, Syahrin. Teologi Kerukunan. Jakarta: Prenada, 2011.

Ja'fari, Fadil Su'ud. Islam Syiah. Malang: UIN-Maliki Press, 2010.

Jurnal Nasional Newspaper (Tuesday, 28 August 2012).

Lane, A. W. Arabic-English Lexeion. Cambridge-England: The Islamic Society Trust, Format in 1984.

Lewis, Bernard. Bahasa Politik Islam. transl. by Ihsan Ali Fauzi. Jakarta: Gramedia, 1994.

Madjid, Nurcholish. Islam Doktrin dan Pradaban. Jakarta: Paramadina, 1992.

Muhammad, Husein. Mengaji Pluralisme kepada Mahaguru Pencerahan. Bandung: Mizan, 2011.

Nasution, Harun. Teologi Islam: Aliran-Aliran Sejarah Analisa Perbandingan. Jakarta: UI Press, 1986.

Rafi'i, Musthafa. Islam Kita: Titik Temu Sunni-Syi'ah. Jakarta: Milestone, 2013.

Republika. "Menteri Agama Kutuk Kekerasan Agama Sampang", in http://www.republika.co.id/berita/nasional/umum/12/08/27/ m9e6y5-menteri-agama-kutuk-tindak-kekerasan-Shi'a-sampang. 27 August 2012.

Sachedina, Abdul Aziz. Kesetaraan Kaum Beriman: Akar Pluralisme Demokratis dalam Islam, transl. Satrio Wahono Jakarta: Serambi, 2002.

Shak'ah (al), Muștafā. Islām bi Là Madhāhib. Cairo: al-Dār al-Miṣriyah alLubnaniyah, the $14^{\text {th }}$ edition, 2000.

Simpson, J. A. dan Weiner, E. S. C. The Oxford English Dictionary. Vol. XI. Oxford: Clarendon Press, the $2^{\text {nd }}$ edition, 1989.

Syam, Nur. Tantangan Multikulturalisme Indonesia. Yogyakarta: Kanisius, 2009. 
Said Agil Siradi

Waspada Online, "Kekerasan Atas Nama Agama Meningkat", in http://www.waspada.co.id/index.php?option=com content\&vi ew $=$ article\&id $=264754$ :kekerasan-atas-nama-agama-meningkat\&catid=77:fokusutama\&Item id=131. 21 October 2012.

Zaqzuq, Mahmud Hamdi. Reposisi Islam di Era Globalisasi. transl. Abdullah Hakam Syah. Yogyakarta: Pustaka Pesantren, 2004. 